\title{
O FINANCIAMENTO DA EDUCAÇÃO NA CONSTITUIÇÃO FEDERAL DE 1988: 30 ANOS DE MOBILIZAÇÃO SOCIAL
}

\author{
José Marcelino de Rezende Pinto $^{1}$ (D)
}

\begin{abstract}
RESUMO: $\mathrm{O}$ artigo analisa a estrutura de financiamento da educação prevista na Constituição Federal. São analisadas suas principais modificaçóes, particularmente a constitucionalização dos fundos de financiamento da educação básica (Fundef e Fundeb) e o princípio do padrão mínimo de qualidade de ensino (CAQi). Finalmente, são analisados alguns efeitos desse modelo de financiamento, particularmente no que se refere às questôes federativas e à redução das desigualdades.
\end{abstract}

Palavras-chave: Constituição Federal. Vinculação de recursos. Fundo de Manutenção e Desenvolvimento da Educação Básica e de Valorização dos Profissionais da Educaçáo. Custo Aluno-Qualidade inicial.

\section{THE FINANCING OF EDUCATION IN THE FEDERAL CONSTITUTION OF 1988: 30 YEARS OF SOCIAL MOBILIZATION}

ABSTRACT: The article analyzes the financing structure of education provided by the Federal Constitution. Its main changes are analyzed, in particular the constitutionalization of the special funds for basic education (Fundef and Fundeb) and the principle of the minimum quality standard of education (CAQi). Finally, some effects of this financing model are analyzed, particularly with regard to federative issues and the reduction of inequalities.

Keywords: Federal Constitution. Earmarked resources. Fund for the Maintenance and Development of Basic Education and Valuation of Education Professionals. Initial Student Cost-Quality.

\footnotetext{
${ }^{1}$ Universidade de São Paulo, Faculdade de Filosofia, Ciências e Letras de Ribeirão Preto Ribeirão Preto (SP), Brasil. E-mail: jmrpinto@ffclrp.usp.br DOI: 10.1590/ES0101-73302018203235
} 


\title{
LE FINANCEMENT DE L'ÉDUCATION DANS LA CONSTITUTION FÉDÉRALE DE 1988 : 30 ANS DE MOBILISATION SOCIALE
}

\begin{abstract}
RÉSUMÉ: Cet article examine la structure de financement de l'éducation prévue par la Constitution Fédérale. Ses principaux changements sont analysés, notamment la constitutionnalisation des fonds du financement de l'éducation élémentaire (Fundef et Fundeb) et le principe du niveau minimum de qualité de l'éducation (CAQi). Enfin, certains effets de ce modèle de financement sont analysés, en particulier en ce qui concerne les questions fédératives et la réduction des inégalités.
\end{abstract}

Mots-clés: Constitution fédérale. Ressources liées à l'éducation. Fonds pour le maintien et le développement de l'éducation de base et la valorisation des professionnels de l'éducation; . Qualité initiale des coûts des étudiants.

\section{Introdução}

A

preocupação de assegurar um amparo legal para o financiamento da educação tem uma longa história. Como apontam Oliveira e Adrião (2002), já em 1647, na então Colônia de Massachusetts, Estados Unidos, uma lei determinava que toda cidade com 50 residências deveria nomear e pagar os salários de um professor de leitura e escrita. Já no Brasil, a sistemática de garantia de recursos para a educação também tem uma longa história. Didaticamente, ela pode ser dividida em três períodos, o último deles com duas complementaçóes importantes. O primeiro corresponde ao monopólio dos jesuítas, que durou de 1549 a 1759, quando a ordem religiosa foi expulsa de Portugal e do reino. $\mathrm{O}$ segundo, em que se contou com uma fonte específica na forma do Subsídio Literário ou com dotaçóes orçamentárias arbitrárias para a educação. E o terceiro momento, que nasce em 1934 com o estabelecimento da vinculação constitucional de recursos para a educação e que, salvo interrupçóes nos períodos ditatoriais, permanece em vigência até hoje. Esse último período, contudo, sofreu duas alterações importantes nos últimos 20 anos que merecem o devido destaque, tendo em vista as suas implicaçóes para o financiamento da educação. A primeira alteração corresponde à política de subvinculação pelo mecanismo de fundos constitucionais, iniciada em 1997 com a Emenda Constitucional (EC) no 14/96, que criou o Fundo de Manutenção e Desenvolvimento do Ensino Fundamental e de Valorização dos Profissionais do Magistério (Fundef), depois substituído pelo Fundo de Manutenção e Desenvolvimento da Educação Básica e de Valorização dos Profissionais da Educação (Fundeb) por meio da EC no 53/2006, cujo fim está previsto para 2020, uma vez que se ancora em disposiçóes transitórias da Constituição Federal. A segunda refere-se à garantia de recursos que assegurem um padrão mínimo de qualidade de ensino, também de 
base constitucional, conceito definido pela EC no 14/96, mas cuja implantação, de forma mais objetiva, foi estabelecida em lei por intermédio do Plano Nacional de Educação (PNE) 2014-2014 (Lei n. 13.005/2014) na forma do Custo Aluno-Qualidade inicial (CAQi), cuja vigência deveria se iniciar em junho de 2016 (BRASIL, 2014), o que não aconteceu, entre outros motivos, pelos efeitos da EC no 95/2016, que congelou os gastos primários da União por 20 anos (BRASIL, 2016b).

Sobre o primeiro período, pode-se afirmar que a política adotada pelo Estado português foi de total desresponsabilizaçáo pela oferta educacional. $\mathrm{O}$ atendimento, usando uma linguagem atual, foi terceirizado aos jesuítas que recebiam, como contrapartida, o monopólio do ensino em Portugal e em todo o reino; já os recursos para a manutenção das escolas, obrigação não cumprida pela Coroa, advinham da renda das vastas extensóes de terras e propriedades recebidas, além dos privilégios de comércio altamente rentáveis (MONLEVADE, 1997). A empresa jesuítica no campo educacional foi significativa, havendo, quando de sua expulsão, em 1759, escolas de primeiras letras em todas as vilas e 17 colégios espalhados pelo país (ROMANELLI, 2003).

Com a expulsão dos jesuítas de Portugal e do reino "como se nunca houvessem existido" (apud ALMEIDA, 1989, p. 32), como consta do Alvará Régio de 1759, ocorreu uma evidente desorganização no padrão de oferta do ensino. Para a manutenção do sistema de aulas régias, então criado, foi aprovado o subsídio literário mediante a Carta Régia de 1772, 13 anos após a expulsão daquela ordem religiosa. Esse mecanismo de financiamento consistia na tributação de dez reais (moeda da época) em cada canada (2.622 L) de aguardente e de um real em cada arrátel $(0,429 \mathrm{~kg}) \mathrm{de}$ carne vendida nos açougues (ALMEIDA, 1989). É fácil imaginar o mínimo impacto arrecadador de um sistema como esse em uma colônia de base econômica agrícola e com uma população urbana insignificante. Se, atualmente, a sonegação sobre esses dois produtos é enorme, o que dizer há mais de dois séculos. Estudo feito por Morais e Oliveira (2012) sobre a Comarca de Ouro Preto, antiga Vila Rica, para os anos de 1795-1797, mostra que ante uma contratação autorizada de três professores de Retórica, três de Filosofia, nove de Gramática Latina e 30 professores de primeiras letras, a receita anual do subsídio literário mal era suficiente para pagar três professores das cadeiras especializadas, ou nove professores de primeiras letras, os quais recebiam cerca de um terço da remuneração de seus colegas que lecionavam nas cadeiras específicas.

Com a independência, não obstante a existência de iniciativas que buscaram incluir, seja na legislação ordinária, seja na Constituição de Império, a vinculação de parte da receita para a educação, nada foi feito (MELCHIOR, 1997; MONLEVADE, 1997), permanecendo apenas o subsídio literário, que só foi extinto com o Ato Adicional de 1834. Ante a ausência de uma fonte estável para o financiamento da educação e com a retirada do governo central, ente que possuía a maior parte dos recursos, do ensino primário e do secundário, assiste-se, nos cem anos seguintes, à construção de um sistema educacional mantido basicamente pelos entes estaduais, parco de recursos e que refletia as desigualdades regionais de riqueza. Um nítido retrato da educação brasileira 
ao fim do século XIX é feito por Almeida (1989), mostrando a ausência de cursos de formação de professores, os baixos salários docentes e o desprestígio da escola pública.

Todo esse cenário é convulsionado pelos movimentos políticos, militares e sociais que marcaram as três primeiras décadas do século XX e que vão desaguar na Revolução de 1930 e de 1932 e na aprovação da Constituição Federal (CF) de 1934. Nessa Carta Magna, é estabelecido o princípio da destinação de um percentual mínimo da receita de impostos dos entes federados para a manutenção e o desenvolvimento do ensino. Inaugura-se a norma constitucional da vinculação de recursos para a educação. Essa norma constitucional teve uma história atribulada, ficando ausente na CF de 1937, retornando em 1946, sendo novamente suprimida na CF de 1967, retornando apenas para os municípios com a EC no 1 , em 1969. É restabelecida, em 1983, por meio da Emenda Calmon e se consolida na CF de 1988, que será analisada no próximo item. Embora a ideia da vinculação, como já comentado, tenha uma longa história no Brasil, para sua transformação em princípio constitucional foi fundamental o papel dos educadores articulados em torno do Manifesto dos Pioneiros da Educação Nova, particularmente de Fernando Azevedo e Anísio Teixeira, especialmente esse último, influenciado pela experiência de financiamento dos Estados Unidos que articulava vinculação de recursos a um fundo administrado por um conselho distrital (MARTINS, 2011; MARTINS; PINTO, 2014). A CF de 1934 consagra a vinculação, e até adota o conceito de "fundos de educação", em seu art. 157, mas destinado apenas a obras e com fontes instáveis de financiamento. Seriam necessários mais 62 anos para que os fundos, com fontes significativas de recursos, fossem incorporados à sistemática constitucional de financiamento da educação por meio do Fundef e do Fundeb.

\section{A Constituição Federal de 1988 e o financiamento da educação}

O financiamento da educação na CF de 1988 já foi exaustiva e profundamente analisado em vários trabalhos (PINTO, 1989; MONLEVADE, 1997; MELCHIOR, 1997; MARTINS, 2011; AMARAL, 2012); o que se pretendeu neste artigo foi realizar uma avaliação sobre o impacto do texto constitucional e suas alteraçôes sobre as políticas de financiamento.

Em seu art. 212, a CF de 1988 estabelece que a União aplicará, anualmente, nunca menos de 18, e os estados, o Distrito Federal (DF) e os municípios $25 \%$, no mínimo, da receita líquida de impostos (RLI) na manutenção e desenvolvimento do ensino (MDE) (BRASIL, 1988). Para o cálculo da RLI, somam-se, à receita dos entes federados, as transferências constitucionais recebidas e abatem-se as transferidas. Em relação aos percentuais mínimos estabelecidos na Emenda Calmon, a única alteração foi a ampliação do índice da União, que passou de 13 para 18\%. Segundo Melchior (1997), essa ampliação se deu no sentido 
de evitar a reduçáo dos recursos federais para o ensino, tendo em vista que, na CF de 1988, houve uma perda relativa da União na divisão do bolo de impostos, de tal forma que os $13 \%$ de antes, em termos de recursos, corresponderiam aos $18 \%$ atuais.

A primeira consequência da consolidação da vinculação constitucional de recursos foi uma ampliação dos recursos disponíveis para a educação em relação ao período em que ela esteve suprimida, em particular, na ditadura militar. Assim, segundo dados do Ministério da Educação (MEC) (BRASIL, 1985), em 1970, os gastos governamentais com educação (conceito mais amplo que manutenção e desenvolvimento do ensino) correspondiam a 2,8\% do Produto Nacional Bruto (PNB). Com a introdução da vinculação constitucional esse patamar passou para a faixa de $4 \%$ do Produto Interno Bruto (PIB), utilizando-se agora o conceito de MDE, que é mais restrito (PINTO, 2000). Aliás, a questão da definição de quais gastos podem ser contabilizados como de MDE é uma consequência natural do princípio da vinculação. Ou seja, se há a exigência de um percentual mínimo da receita de impostos que deve ser destinado para MDE, é essencial definir o que pode ser contabilizado como tal. Coube à Lei de Diretrizes e Bases da Educação (LDB) (Lei no 9.394/96), em seu art. 70, definir aquelas despesas que podem ser contabilizadas como MDE e, em seu art. 71, estabelecer aquelas que não podem (BRASIL, 1996a). Não obstante a existência de dois artigos para regular o tema, a lei acabou deixando brechas que são utilizadas para inflar os gastos educacionais. A mais crítica delas é a omissão do pagamento dos profissionais da educação aposentados, que não aparece nem no art. 70 nem no art. 71 . E cabe dizer que náo se trata de esquecimento do legislador, pois quando da elaboração da lei, o tema dos inativos apareceu em diferentes momentos do projeto de lei, seja como MDE, seja como não MDE. Na versão final da lei, o item acabou sendo retirado, gerando os problemas atuais. Felizmente, no âmbito jurídico a contabilização dos aposentados como MDE está sendo questionada no Supremo Tribunal Federal (STF), por meio da Ação Direta de Inconstitucionalidade (ADI) n. 5.719/2017, proposta pelo então Procurador Geral da República Rodrigo Janot (STF, 2017). No mesmo sentido, decisão recente do Tribunal de Contas do Estado de São Paulo (TEC-SP) determinou que o Governo Alckmin, a partir do orçamento de 2018, retire da contabilização de MDE os gastos com inativos. Na mesma decisão, o relatório do TCE-SP mostra que, em 2016, foram contabilizados como MDE R \$ 6,5 bilhóes referentes a pagamento de servidores aposentados da educação. A não contabilização desses gastos faria o percentual destinado à MDE baixar de 31 para $25 \%$, sendo que o mínimo definido pela Constituição Estadual é 30\% (SALDAÑA, 2017).

Uma segunda consequência da vinculação de impostos, especialmente por parte da União, foi a busca de mecanismos que permitissem ampliar sua receita tributária sem, com isso, aumentar a receita de impostos. Isso ocorreu por meio da criação e da ampliação de alíquotas das contribuiçóes sociais e econômicas. Cabe dizer que esse tipo de tributo, que inclui, entre outras, as contribuiçóes previdenciárias, 
a Contribuição para o Financiamento da Seguridade Social (Cofins) e a Contribuição Social Sobre o Lucro Líquido, foi uma inovação da CF de 1988, com o objetivo, entre outros, de financiar as políticas de seguridade social, aposentadorias e saúde. Acontece que, como a experiência mostrou, quando ocorre superávit no sistema, os recursos adicionais acabam entrando no caixa do Tesouro e são utilizados para o pagamento da dívida pública ou outras despesas de interesse do Executivo. Por outro lado, para qualquer imposto criado, ou majorado, o governo federal deve destinar $18 \%$ para MDE e $15 \%$ para a saúde, além das transferências constitucionais de impostos para estados, DF e municípios. Essas transferências, em 2016, representaram mais de $42 \%$ da receita de impostos da União (BRASIL, 2016c). Em vista disso, o governo federal optou por ampliar a receita das contribuiçóes, que saltaram de um patamar de 10\% do PIB no período 1995-1997 (PINTO, 2000) para 14,2\% em 2015 (RECEITA FEDERAL, 2016), um acréscimo superior a 40\%.

Uma contribuição social possui particular importância para o financiamento da educação. Trata-se do salário-educação, criado inicialmente pela Lei no 4.440/1964, no primeiro ano do golpe militar, que adquiriu status constitucional na CF de 1969, outorgada pelos militares em plena vigência do Ato Institucional Número 5 (AI5) e que continua existindo, com alteraçôes, até hoje. Como aponta Melchior (1997), desde 1946 havia a obrigatoriedade constitucional das empresas, a partir de certo número de empregados, oferecerem ensino primário gratuito para os seus empregados analfabetos, bem como para seus filhos na faixa etária correspondente. Contudo, poucas empresas cumpriam esse dever constitucional. Com a nova legislação, foi aberta a possibilidade de cumprir a obrigação mediante a contribuição do salário-educação (art. 178). O ponto de partida para fixação de sua alíquota, ainda segundo Melchior (1997), foi um estudo de custo/aluno na escola primária realizado pelo Instituto Nacional de Estudos e Pesquisas Educacionais Anísio Teixeira (INEP), que chegou a um valor de $7 \%$ do salário mínimo. Em valores atuais, corresponderia a $\mathrm{R} \$ 67 /$ mês por aluno, valor claramente subdimensionado, mesmo considerando a perda de poder aquisitivo do salário mínimo no período. Com base nessa estimativa de custo, chegou-se a uma alíquota de 1,4\% sobre a folha mensal de contribuição das empresas ao então Instituto Nacional de Previdência Social (INPS). Com ampliação da obrigatoriedade escolar para oito anos, em 1969, tornou-se necessária a ampliação da alíquota, o que só ocorreu em 1975, passando de 1,4 para 2,5\%, ou seja, sem corresponder sequer à duplicação dos anos de obrigatoriedade. Desde seu início, a legislação permitiu que parte dos recursos do salário-educação fosse destinada a escolas privadas. A CF de 1988, em sua versão original, manteve as características do tributo vindas do período ditatorial (art. 212, \$50). Uma mudança importante ocorreu com a EC no 14/1996, a mesma que criou o Fundef, que estabeleceu que os recursos do salário-educação só poderiam ser utilizados no ensino público. Finalmente, a mudança mais recente se deu com a aprovação da EC no 53/2006, que criou o Fundeb e alterou mais uma vez a redação do $\$ 5^{\circ}$ do art. $212 \mathrm{da} \mathrm{CF}$, estabelecendo que seus recursos poderiam ser utilizados para toda a 
educação básica e não apenas para o Ensino Fundamental, como ocorria até então. Não houve, contudo, nenhuma preocupação do legislador em ampliar a alíquota, ou base tributária da contribuição, não obstante o grande número de novos estudantes que passaram a ter direito à contribuição. A título de registro, vale comentar que o Projeto Substitutivo de LDB, que teve como relator o entáo Deputado Jorge Hage, estabelecia a alíquota em 3,5\% e ainda criava o salário-creche, com alíquota de $1 \%$ (PINTO, 2002). Outra mudança feita pela EC no 53/2006 foi o acréscimo do $\$ 6^{\circ}$ ao art. 212, estabelecendo a existência de uma quota municipal, situação que se arrastava há anos sem solução, e determinando também que o critério da distribuição entre estados e municípios dos recursos que lhes cabem (atualmente, 60\% da arrecadação líquida) seria o número de alunos matriculados na educação básica na respectiva rede. Nos últimos 20 anos, o salário-educação tem mantido uma arrecadação de 0,3\% do PIB, com muita estabilidade, mesmo considerando a redução do peso do fator trabalho nas empresas. Em 2016, sua receita foi de R \$ 19 bilhóes e os recursos da cota federal têm sido utilizados majoritariamente nos programas de alimentação escolar, transporte escolar, livro didático e no Programa Dinheiro Direto na Escola (PDDE), e são gerenciados pelo Fundo Nacional de Desenvolvimento da Educação (FNDE), autarquia vinculada ao MEC. Uma última curiosidade sobre o salário-educação: dividindo-se sua receita de 2016 pela matrícula da educação básica pública, chega-se a $\mathrm{R} \$ 40 / \mathrm{mês}$, um valor $40 \%$ inferior àquele que serviu de referência para sua criação, visto no início desse parágrafo.

Cabe comentar a existência de outra contribuição social no campo da educação e que se destina ao Sistema “S”. Sua receita, em 2016, foi de R\$ 18 bilhões, só que boa parte dela é apropriada pelas entidades patronais da indústria, da agricultura e do comércio, que a utiliza sem qualquer transparência ou controle social. Tem-se aqui, evidentemente, uma aberraçáo, pois se trata de um tributo de natureza indireta, recolhido, pelas empresas, como ocorre com o salário-educação, mas que, embutido no preço dos produtos, é pago, portanto, pelo conjunto da sociedade, só que apropriado de forma privada. E o mais grave, mesmo recebendo um volume gigantesco de recursos públicos, é que boa parte dos cursos oferecidos pelo Sistema "S" é paga.

A estratégia mais ostensiva de fuga da vinculação se deu com a criação do Fundo de Estabilização Fiscal (FEF). Nascido com o sugestivo e enganador nome de Fundo Social de Emergência (FSE), por meio da EC de Revisão no 1/1994, com o objetivo declarado de "saneamento financeiro da Fazenda Pública Federal e de estabilização econômica, cujos recursos serão aplicados prioritariamente no custeio das ações dos sistemas de saúde e educação", conforme art. 71 Ato das Disposiçóes Constitucionais Transitórias (ADCT) (BRASIL, 1988), e com duração prevista apenas para os anos de 1994 e 1995. Sua principal fonte correspondia a $20 \%$ da arrecadação de todos os impostos e contribuiçóes da União, inclusive os que fossem criados (BRASIL, 1988). Já em 1996, seu nome foi mudado para FEF (EC no 10/1996), motivação real de sua criação, sendo prorrogado até 1999 , 
quando foi substituído pela Desvinculação das Receitas da União (DRU) (EC no $27 / 2000$ ), que manteve a alíquota de $20 \%$ sobre a arrecadação de impostos e contribuiçóes sociais da União, excluindo-se o salário-educação de seus efeitos (BRASIL, 1988). Com a EC no 59/2009 (BRASIL, 2009), os efeitos da DRU sobre a educaçấo foram progressivamente reduzidos, caindo sua alíquota para 12,5\%, em 2009; 5\%, em 2010; até a extinção completa, em 2011. Finalmente, por meio da EC no 93/2016 (BRASIL, 2016a), a DRU foi prorrogada até 2023, ampliando-se a alíquota para 30\%, mas incidindo apenas sobre as contribuiçóes sociais e de intervenção no domínio econômico, mantendo-se a não aplicação de seus efeitos sobre a contribuiçáo do salário-educação. Tomando por base o ano de 2016, o volume que é retirado das políticas sociais pela DRU corresponde a 3,5\% do PIB. São recursos que deveriam ir para a saúde e previdência social e que são desviados para o pagamento de juros aos rentistas que aplicam em títulos da dívida pública. A mesma emenda estabeleceu a desvinculação da receita de impostos, taxas e multas de estados, DF e municípios, com alíquota de 30\%, excluindose de seus efeitos as vinculações à educação e saúde (arts. 76-A e 76-B ADCT) (BRASIL, 1988).

Durante os 18 anos em que estiveram em vigor para os recursos educacionais, os mecanismos de desvinculação da receita de impostos da União (FSE, FEF e DRU) confiscaram 2,9\% do PIB que seria destinado ao ensino. Do ponto de vista didático, os $18 \%$ de impostos da Uniáo previstos na CF para MDE se transformaram em $14,4 \%$.

Outro mecanismo que também afeta muito a vinculação é a sonegação de impostos. Levantamento do Sindicato Nacional dos Procuradores da Fazenda Nacional (Sinprofaz) aponta que, em 2016, a sonegação atingiu R $\$ 500$ bilhóes (NUNES, 2017), cerca de 8\% do PIB. Outra sangria de recursos vem das desoneraçóes tributárias para determinados setores da economia. Por exemplo, a isenção de Imposto sobre Produtos Industrializados (IPI) para o setor automobilístico e os produtos da chamada linha branca representou uma perda anual para a educação da ordem de 0,2\% do PIB, cerca R\$ 13,5 bilhóes, em valores de 2016 .

Um último efeito da política de vinculação, que não decorre da vinculação em si, mas do desequilíbrio do federalismo brasileiro, refere-se à grande diversidade nos recursos disponíveis por aluno entre as diferentes regióes do país, assim como no interior de uma mesma região entre as redes municipal e estadual, como mostra a Tabela 1 .

Os dados da Tabela 1, que refletem uma situação anterior à política de fundos, apontam, inicialmente, o diferencial que representa a rede federal em relaçâo às demais. No caso do Ensino Médio, o gasto/aluno dessa rede chega a ser dez vezes maior que a rede estadual. No caso do Ensino Fundamental, o maior valor (rede municipal do Sudeste), em 1995, era mais que o triplo do menor valor (redes municipais do Norte e do Nordeste). No caso da Educação Infantil, essa diferença chegava quase 
a cinco vezes (Sudeste municipal versus Norte municipal). Constata-se, ainda, a Região Nordeste como aquela onde maiores eram as diferenças entre gasto aluno na rede estadual e na municipal. Esse foi, entre outros motivos, a justificativa para a implantação da política de fundos que será analisada mais adiante.

Outro tema constitucional de forte impacto refere-se à destinação de recursos públicos para o setor privado de ensino. Essa questáo polêmica possui uma longa história no país, a começar pelo período jesuítico, uma parceria público-privada passando pelo sistema de Caixa Escolar, de triste memória, previsto na CF de 1937. Essa questão foi, inclusive, um dos fatores que explicam a demora na aprovação da Lei de Diretrizes e Bases de 1961 (Lei no 4.024/1961) (ROMANELLI, 2003). A saída adotada por essa lei reforçava a ideia de que cabia à família escolher o tipo de escola, pública ou privada, que desejasse encaminhar seu filho e, em caso de falta de recursos, caberia ao Estado fornecê-los para que a família pudesse exercer seu "direito de escolha" (art. 3º, inc. II) (BRASIL, 1961), uma lógica muito similar aos sistemas de Voucher propagados a partir dos Estados Unidos. Já na CF de 1969 (BRASIL, 1969), a gratuidade em estabelecimentos oficiais só era garantida para o ensino primário, determinando a gradativa substituição, no Ensino Médio (que incluía os atuais anos finais do Ensino Fundamental) e Superior, da gratuidade por bolsas de estudos reembolsáveis, além de, explicitamente, estabelecer que a iniciativa privada receberia amparo técnico e financeiro dos poderes públicos, inclusive mediante bolsas de estudo (art. 176). Nesse contexto, a CF de 1988 foi um inegável avanço das teses publicistas em favor de recursos públicos apenas para escolas públicas. Nesse sentido, cabe comentar o princípio da gratuidade do ensino público em estabelecimentos oficiais (art. 206, inc. IV), determinação que, de forma surpreendente, foi interpretada recentemente pelo STF como se referindo apenas ao ensino regular, abrindo uma alameda para cobranças nos cursos pós-graduação lato sensu nas universidades públicas (BRASIL, 1988). O aspecto mais crítico da

\section{Tabela 1}

Gasto médio por aluno na educação básica por dependência administrativa nas diversas regiōes do país, 1995 (em R\$).

\begin{tabular}{lcccccc}
\hline \multirow{2}{*}{ Regiáo } & \multicolumn{2}{c}{ Ed. Infantil } & \multicolumn{2}{c}{ E. Fundamental } & \multicolumn{2}{c}{ E. Médio } \\
\cline { 2 - 7 } & Estado & Município & Estado & Município & Federal & Estado \\
\hline Norte & 356 & 226 & 350 & 209 & 5.479 & 347 \\
\hline Nordeste & 410 & 239 & 357 & 211 & 4.079 & 367 \\
\hline Sudeste & 706 & 1.017 & 581 & 696 & 4.881 & 580 \\
\hline Sul & 468 & 739 & 455 & 658 & 3.414 & 486 \\
\hline Centro-Oeste & 468 & 517 & 440 & 499 & 4.576 & 487 \\
\hline Brasil & 513 & 568 & 502 & 418 & 4.495 & 522 \\
\hline
\end{tabular}

Fonte: adaptado de Castro e Fernandes (1999). 
questão encontra-se, contudo, no art. 213, que estabelece que os recursos públicos poderão ser destinados a instituiçôes privadas comunitárias, confessionais ou filantrópicas, desde que comprovem finalidade não lucrativa e destinem seu patrimônio a outra escola de mesma natureza em caso de fechamento. $\mathrm{O}$ parágrafo primeiro do mesmo artigo ainda estabelece que esses recursos podem ser destinados a bolsas de estudo (sempre elas) no Ensino Fundamental e Médio, conforme regulamentação legal, para aqueles que demonstrem insuficiência de recurso, quando houver falta de vagas na rede pública. $\mathrm{O}$ mesmo parágrafo estabelece, contudo, que o Poder Público fica obrigado a investir prioritariamente na expansão de sua rede na localidade. Nos primeiros anos de vigência da CF de 1988, pode-se dizer que prevaleceu a lógica do recurso público para o setor privado como exceção (BRASIL, 1988). Todavia, especialmente a partir da aprovação das políticas de reforma do Estado no Governo Fernando Henrique Cardoso (FHC) e, em especial, com a aprovaçáo do Programa Universidade para Todos (PROUNI) e do Fundo de Financiamento ao Estudante do Ensino Superior (FIES), no caso da educaçáo superior, e do Fundeb, com a permissão de contabilização de alunos conveniados na Educação Infantil e Especial, houve uma clara inflexão, fazendo com que recursos públicos significativos fossem destinados para o setor privado de ensino, como mostra ampla bibliografia (PERONI, 2003; ADRIÁO, PERONI, 2007; PERONI; OLIVEIRA; FERNANDES, 2009; ADRIÃO; PINTO, 2016; PINTO, 2016, entre outros). Apenas um exemplo: estudo do Ministério da Fazenda (BRASIL, 2017) mostra que o custo do FIES, em 2016, incluindo-se os subsídios implícitos (os quais são contabilizados para efeito de cumprimento da meta 20 do PNE) chegou a $0,5 \%$ do PIB, o equivalente a todo o gasto federal (MDE) com educação superior pública.

\section{A política de fundos e o custo aluno-qualidade inicial}

De forma análoga à vinculação constitucional, há uma ampla e cuidadosa produção bibliográfica sobre a política de fundos contábeis inserida na CF de 1988, a partir da aprovação do Fundef, por meio da EC no 14/1996 (MELCHIOR, 1997; MONLEVADE; FERREIRA, 1997; ARELARO, 1999; PINTO, 1999; 2000; 2007; DAVIES, 2006; CURY, 2007; SENA, 2008; 2011; ARAÚJO, 2012, entre outros). O que se pretende aqui é analisar os principais efeitos do Fundef e do Fundeb nas políticas públicas. Um primeiro comentário geral deve ser feito sobre a fragilidade institucional da política de fundos, uma vez ancorada nas disposiçóes transitórias da CF de 1988, mais particularmente no art. 60 do ADCT. O Fundef nasce em um contexto de forte alinhamento do Governo FHC com os organismos internacionais, em especial com o Banco Mundial, na perspectiva da focalizaçáo no Ensino Fundamental e na descentralização (PINTO, 2002). Há também outro forte elemento de contexto que foi o descumprimento, por parte da Uniáo, do art. 60 do ADCT, na versão original da CF de 1988, que determinava que pelo menos a metade dos recursos vinculados 
definidos no art. 212 fosse destinada à universalização do Ensino Fundamental é à erradicação do analfabetismo (BRASIL, 1988). Inquestionavelmente, o efeito de maior impacto e, praticamente irreversível, do Fundef foi alterar a divisão pela responsabilidade na oferta educacional no país. Assim, desencadeou-se um processo de municipalização do Ensino Fundamental sem precedentes, de tal forma que, nos 40 anos anteriores ao Fundef, estados e municípios dividiam a oferta do atendimento público dessa etapa, respondendo os primeiros por dois terços das matrículas e os segundos por um terço, em razão muito próxima da distribuição entre eles da receita de impostos; ao final do fundo, essa divisão da oferta praticamente se inverteu (PINTO, 2014). É importante ressaltar que o processo foi mais intenso nas regióes mais pobres do país e foi motivado basicamente pela vinculação entre repasse de recursos do fundo e matrícula no Ensino Fundamental regular. O Fundef provocou também um abandono da Educação Infantil por parte daquelas redes estaduais que também atendiam a essa etapa; o mesmo fenômeno acontecendo em relação ao Ensino Médio, no caso das redes municipais. Uma das consequências esperadas do fundo era um congelamento ou uma redução no crescimento das matrículas na Educação Infantil, o que não aconteceu. Com base nos dados do Censo Escolar (MEC, 1997 a 2016), constata-se que, de 1997 a 2006 , as matrículas em creche cresceram $294 \%$, e na pré-escola, 26\%. O inesperado grande crescimento, especialmente nas creches, pode ser explicado por uma melhora na contabilização dos dados, uma vez que essa etapa, antes da CF de 1998 e da LDB de 1996, encontrava-se geralmente na área de assistência social. Outros fatores que explicam o crescimento foram a pressão pela demanda e o novo papel assumido pelo Ministério Público (MP), uma vez que, com a CF de 1988, a Educação Infantil passou a ser direito dos pais e dever do Estado. De qualquer forma, uma vez que houve uma priorização dos recursos no Ensino Fundamental, essa expansão aconteceu em um cenário de restrição de recursos, com riscos à qualidade de ensino. Outro temor, com o Fundef, deu-se em relação à Educação de Jovens e Adultos (EJA), uma vez que os alunos dessa modalidade de ensino não eram contabilizados para efeito de recebimento de recursos. Como na Educação Infantil, os dados do Censo Escolar também surpreendem, pois se observa, entre 1998 e 2007, uma expansão de 109\% na matrícula, puxada, principalmente, pela rede municipal. Esse fato pode ser explicado pela entrada em vigor dos programas Recomeço/Fazendo Escola, no período de 2001 a 2006, em que o MEC repassava recursos específicos por aluno para essa modalidade de ensino. Esses dados "inesperados" para Educação Infantil e EJA, mesmo havendo uma clara intencionalidade de focalização no Ensino Fundamental regular por parte da gestão FHC, mostram a capacidade de reação dos setores envolvidos e o caráter dialético da implementação de políticas públicas.

A EC no $14 / 96$ promoveu também uma mudança com forte impacto no desenho futuro do financiamento da educação. Trata-se da nova redação dada aos parágrafos do art. $211 \mathrm{da}$ CF que explicita de forma mais clara as atribuiçóes entre 
os entes federados na oferta educacional. Assim, o $\$ 2^{\circ}$, com redação alterada, estabeleceu que os municípios atuarão de forma prioritária no Ensino Fundamental e na Educação Infantil (na redação anterior era Ensino Fundamental e Pré-escolar); e foi incluído o $₫ 3^{\circ}$, que estabeleceu que os estados e o DF terão como prioridade o Ensino Fundamental e Médio, ou seja, do ponto de vista constitucional, não há nenhuma sinalização para a municipalização do Ensino Fundamental. Porém, a mudança mais interessante para a análise deste artigo ocorreu no $\$ 1^{\circ}$ do art. 211 . A redação original, mais genérica, estabelecia que, além de cuidar de sua rede, a União deveria prestar assistência técnica e financeira aos estados, ao DF e aos municípios para o desenvolvimento de seus sistemas de ensino e o atendimento prioritário à escolaridade obrigatória. Já com a nova redação, os compromissos da União são ampliados e melhor explicitados. Assim, além de cuidar do sistema federal de ensino, ela exercerá "função redistributiva e supletiva de forma a garantir equalização de oportunidades educacionais e padrão mínimo de qualidade de ensino mediante assistência técnica e financeira" (BRASIL, 1996a). E na nova redação do art. 60 do ADCT, que tratava do Fundef, ficou estabelecido que caberia à Uniáo complementar os recursos do fundo, em cada Estado e no DF, sempre que o valor por aluno não atingisse o mínimo definido nacionalmente $\left(\$ 3^{\circ}\right)$, além de determinar que a União, os estados, o DF e os municípios ajustariam suas contribuiçôes ao Fundef de tal forma que, em um prazo de cinco anos, fosse atingido um valor por aluno "correspondente a um padrão mínimo de qualidade de ensino, definido nacionalmente" ( $\$ 3^{\circ}$ do art. 60 do ADCT) (BRASIL, 1996a). Ou seja, estabeleceu-se a data de $1^{\circ}$ de janeiro de 2003 como o prazo para implantação do que veio a se tornar o CAQi (Custo Aluno-Qualidade inicial). Antes desta data, caberia à lei regulamentar, o que foi feito por intermédio da Lei no 9.424/96 (BRASIL, 1996b), que estabeleceu para 1997, primeiro ano do fundo, o valor mínimo anual de $\mathrm{R} \$ 300$ por aluno (art. $6^{\circ} \$ 4^{\circ}$ ), e determinou que, para os anos seguintes, até 2003, esse valor mínimo não poderia ser inferior à razão entre a previsão da receita total do fundo e a previsão de matrícula no Ensino Fundamental (art. $6^{\circ} \$ 1^{\circ}$ ). Ou seja, o valor mínimo deveria ser igual ao valor médio nacional. Isso também nunca foi cumprido durante toda a existência do Fundef (governos FHC e Lula), gerando uma dívida superior a uma centena de bilhóes de reais da União com estados e municípios. Do ponto de vista de sua execução financeira, o Fundef foi uma sequência de descumprimento do padrão mínimo de qualidade e da equalização de oportunidades educacionais. Com base nos Boletins do Fundef elaborados pela Secretaria do Tesouro Nacional (STN) (BRASIL, 2016c), constata-se que, em 1998, primeiro ano em que o fundo foi compulsório para todo o país, a complementação da Uniâo atingiu oito estados (Alagoas, Bahia, Ceará, Maranhão, Pará, Paraíba, Pernambuco e Piauí) e correspondia a 2,5\% dos recursos do fundo, enquanto que, em seu final melancólico de 2006, atingia apenas dois estados (Maranhão e Pará), o que representou menos de $1 \%$ dos recursos totais. 
Tendo em vista a omissão do Executivo na definição e na implantação do CAQi previstas no âmbito da EC no $14 / 96$, em um movimento de mobilização nacional, a Campanha Nacional pelo Direito à Educação, valendo-se de uma metodologia amplamente discutida com pesquisadores da área do financiamento e com os principais atores do campo educacional, lança a proposta do CAQi, em 2007 (CARREIRA; PINTO, 2007), encampada pelo Conselho Nacional de Educação (CNE), por meio do Parecer CNE/Câmara de Educação Básica (CEB) $\mathrm{n}^{\mathrm{o}}$ 8, de 2010, ainda não homologado pelo MEC. Assim, 15 anos após o prazo limite dado pela $\mathrm{EC} \mathrm{n}^{\circ} 14 / 96$, o país ainda não possui o seu CAQi. Como se verá mais adiante, a principal razão para a não homologação do parecer do CAQi é o fato de que sua implementação implicará em um aumento significativo da complementação da União ao Fundeb, na medida que o CAQi, em suas diferentes etapas e modalidades, passa a ser o valor mínimo por aluno desse fundo.

Enquanto isso, por meio da EC no 53/2006 (BRASIL, 2006), foi criado o Fundeb, fundo também transitório, com data de extinção em 31 de dezembro de 2020, o que mantém a fragilidade institucional da política de financiamento da educação no país. Antes de entrar no Fundeb, cabe comentar que essa emenda, como já comentado, criou as quotas municipais do salário-educação (art. $212 \$ 5^{\circ}$ ) e ampliou sua aplicação para toda a educação básica (art. $212 \$ 6^{\circ}$ ), assim como o Piso Salarial Profissional Nacional (PSPN) (art. 206, inc. VIII), medidas essas de impacto positivo no financiamento da educação na perspectiva da equalização de oportunidades e da valorização dos profissionais da educação. Quanto ao Fundeb, fruto do sonho de muitos educadores de fazer valer o princípio do $₫ 1^{\circ}$ do art. 211 da CF e de garantir educação básica de qualidade para todos os brasileiros, cabem alguns rápidos comentários. Em primeiro lugar, entre outros problemas, o projeto enviado pelo Executivo excluía do fundo a contabilização das crianças matriculadas em creche, um atentado ao conceito de educação básica, e estabelecia um valor fixo em reais do complemento da União, questão crítica, como se viu na execução do Fundef. $\mathrm{O}$ texto finalmente aprovado garantiu a inclusão de toda a educação básica em suas diferentes modalidades; estabeleceu a complementação em, no mínimo, $10 \%$ dos aportes feitos por estados, DF e municípios ao fundo; vedou o uso do salário-educação nessa complementação; e limitou o uso dos recursos vinculados (art. 212) em, no máximo, 30\% da complementação (art. 60 ADCT, incs. V, VII e VIII). Escaldados no calote do Fundef, os legisladores estabeleceram ainda que o descumprimento dos valores da complementaçáo da União importa em crime de responsabilidade (art. 60 ADCT, inc. XI). Não obstante esses avanços, aspectos significativos do novo fundo foram deixados para a regulamentação, tais como a fiscalização dos recursos, a definição dos fatores de ponderação entre as etapas e as modalidades de ensino e a forma de cálculo do valor anual mínimo por aluno (art. 60 ADCT, inc. III). E mais grave, a EC no 53/2006 é absolutamente omissa quanto ao CAQi, em claro retrocesso em relação à EC no 14/96.

O Fundeb foi regulamentado pela Lei no $11.494 / 2007$, cuja análise extrapola os objetivos deste artigo, mas cabem, ao menos, dois comentários. O primeiro refere-se 
ao avanço nos mecanismos de controle social, ampliando a participação e restringindo a intervenção dos Executivos, o que, infelizmente, não tem impedido os constantes desvios dos recursos da educação, até porque os Conselhos de Acompanhamento e Controle Social (CACS) atuam apenas sobre os recursos do Fundeb, que não correspondem à totalidade dos recursos para a educação e atuam a posteriori, quando as despesas já foram executadas. Outro aspecto a ser comentado na lei regulamentadora refere-se à total desproporção entre os fatores de ponderação adotados para as diferentes modalidades e seus respectivos custos reais, além da limitação específica de utilização de recursos para a EJA. Um último comentário deve ser feito sobre a política de fundos no que se refere à fixação de um índice mínimo de $60 \%$ do total de recursos do fundo para o pagamento dos professores, no caso do Fundef, e para os profissionais do magistério, no caso do Fundeb. A destinação desse percentual, inclusive, é que justificou a questão da valorização profissional no nome de ambos os fundos. $\mathrm{O}$ que a experiência tem mostrado, contudo, é que, considerando que tanto no caso do Fundef, já extinto, como no caso do Fundeb, os recursos apropriados pelos fundos não correspondem à totalidade dos recursos educacionais e que os gastos com pessoal em educação superam os $80 \%$ do custo total os percentuais fixados pela CF em seu art. 60 do ADCT acabaram não promovendo uma valorização profissional, a não ser nos entes federados que, com o Fundeb, passaram a receber uma complementação significativa por parte da União.

Fechando a discussão do financiamento na $\mathrm{CF}$, resta a mudança feita no art. 214 que trata do PNE, por meio da EC no 59/2009, a mesma que extinguiu aos efeitos da DRU para a educação. Foi feita uma alteração do caput do artigo introduzindo como um dos objetivos do PNE a articulação de um sistema nacional de educação em regime de colaboração. Além disso, foi introduzido o inciso VI, que determina o estabelecimento de meta de aplicação de recursos públicos em educação como proporção do PIB. Para se entender a importância dessa inclusão há que se retomar a história do PNE 2001-2011 (Lei no 10.172/2001), que estabelecia a meta de elevação do percentual de gastos públicos em relação ao PIB, aplicados em educação, para atingir o mínimo de $7 \%$, na proporção de $0,5 \%$ nos quatro primeiros anos e $0,6 \%$ do PIB no quinto ano (item 11.3.1). Como se sabe, essa meta foi vetada pelo então presidente FHC sob a alegação de que ela se chocava com várias determinaçóes constitucionais, tais como as normas relativas ao Plano Pluri Anual (PPA) e à Lei de Responsabilidade Fiscal (LRF). Para evitar o golpe da inconstitucionalidade, foi preciso alterar a CF e o PNE 2014-2024 (Lei no 13.004/2014) fixou a meta de $10 \%$ do PIB até 2024 sem risco de vetos. O que não se imaginava, contudo, era que novo golpe viria com a $\mathrm{EC} \mathrm{n} \mathrm{n}^{\circ} 95$, mas isso é assunto para as consideraçóes finais.

\section{Um olhar sobre os números}

Serão mostrados, a seguir, alguns dados que buscam apontar de que forma esse arranjo constitucional relativo ao financiamento da educação se concretizou. 
No Gráfico 1 é apresentada a evolução do investimento público direto (IPD) em educação, de 1995 a 2014, último ano disponível, conforme metodologia desenvolvida pelo INEP. Embora em Economia o conceito de investimento tenha outro significado, foi adotada a terminologia do INEP. No IPD estão incluídas as despesas feitas pela Uniáo, pelos estados e pelos municípios nos diferentes níveis, etapas de modalidades de ensino. Por outro lado, não estão contabilizadas as despesas com aposentadorias e reformas, pensóes, recursos para bolsas de estudo e financiamento estudantil, despesas com juros e encargos da dívida e amortizaçóes da dívida da área educacional, assim como as transferências correntes e de capital ao setor privado.

Os dados indicam um grande crescimento, em termos reais, dos gastos públicos em educação, que praticamente triplicaram no período, com grande destaque para o intervalo de 2005 a 2010, com crescimento de $79 \%$ em apenas um quinquênio. Cabe salientar que muito desse crescimento é decorrência direta do desempenho da economia, tendo em vista a dependência dos gastos educacionais com a receita de impostos, a qual está intimamente relacionada ao crescimento do PIB.

Portanto, para aquilatar se houve, de fato, uma ampliação do esforço educacional dos entes federados, é importante analisar a evolução do IPD em relação ao PIB, o que é mostrado no Gráfico 2.

Os dados apresentados no Gráfico 2 já apontam um crescimento menor do esforço educacional dos entes federados, que cresceu 25\% de 1995 a 2014, ou seja, ampliação de 1\% do PIB. Trata-se, contudo, de uma evidente mudança no patamar de financiamento, que se deu, basicamente, no período de 2005 a 2010. Portanto, a grande expansão verificada em valores reais apontada no Gráfico 1 decorreu do crescimento do PIB no período. Esse dado reforça a importância da vinculação constitucional de recursos para o ensino, que garantiu para a educação

\section{Gráfico 1}

Evolução do investimento público direto em educação -1995 a 2014 (R \$ bilhóes de 2018).

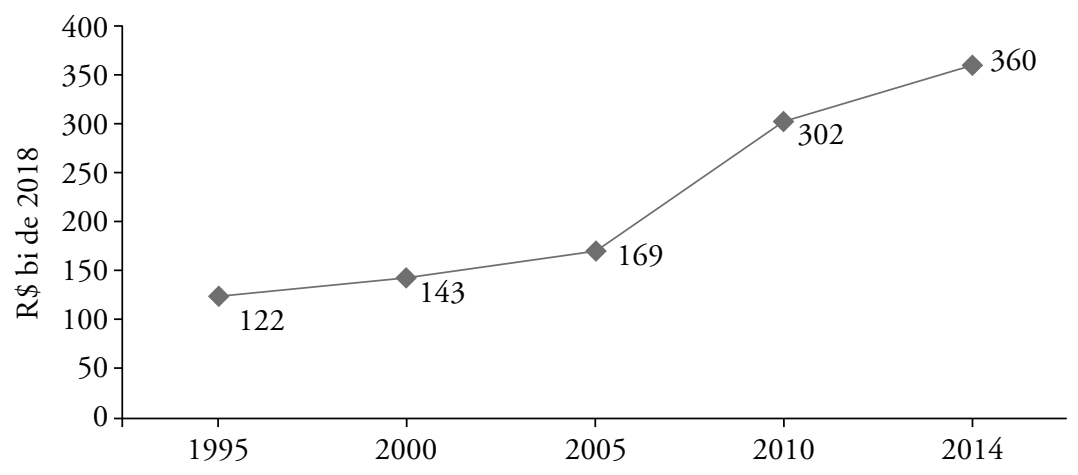

Fonte: INEP, 2015 a (atualizaçâo feita pelo autor). 
os benefícios do crescimento econômico. Com a EC no 95/2016, essa vinculação obrigatória, a partir de 2018, deixa de existir, ao menos para a União, nos termos do art. 110, inciso II, da EC no 95/2016, que estabelece que os gastos com educação devem se sujeitar ao novo regime fiscal, que determina o congelamento das despesas primárias por vinte exercícios financeiros, admitindo-se apenas a correção do total da despesa pelo Índice de Preços ao Consumidor Amplo (IPCA), tomando como referência o exercício financeiro de 2017. É importante ressaltar que o congelamento é sobre a despesa primária total; assim, se em alguma área, como a previdência social, por exemplo, o crescimento for acima da inflação medida pelo IPCA, deverá ocorrer uma queda de valor equivalente em outras áreas de atuação do Governo Federal.

Já o Gráfico 3 apresenta a evolução, em relação ao PIB, no período de 2000 a 2016, de dois indicadores centrais quando se discute o financiamento: o gasto do Governo Federal com MDE e os recursos do Fundef/Fundeb. O primeiro é o principal responsável pela educação superior pública no Brasil, e o segundo, como já discutido, é a principal fonte de financiamento da educação básica no país, composto essencialmente por recursos dos estados e dos municípios (91\%).

Os dados do Gráfico 3 mostram, inicialmente, o pequeno papel que o Governo Federal possui no financiamento da educação, não obstante ficar com mais da metade da receita tributária líquida. Como discutido na primeira parte deste trabalho, essa pequena participação da União decorre dos mecanismos de fuga da vinculação. Um segundo aspecto relevante, ainda com relação ao Governo Federal, é a constatação de que as despesas com MDE dobraram em relação ao PIB no período de 2000 a 2016, e o maior crescimento foi de 2005 a 2012, ano em que o gasto federal atingiu perto

\section{Gráfico 2}

Evolução do investimento público direto em educação - 1995 a 2014 (\% do Produto Interno Bruto).

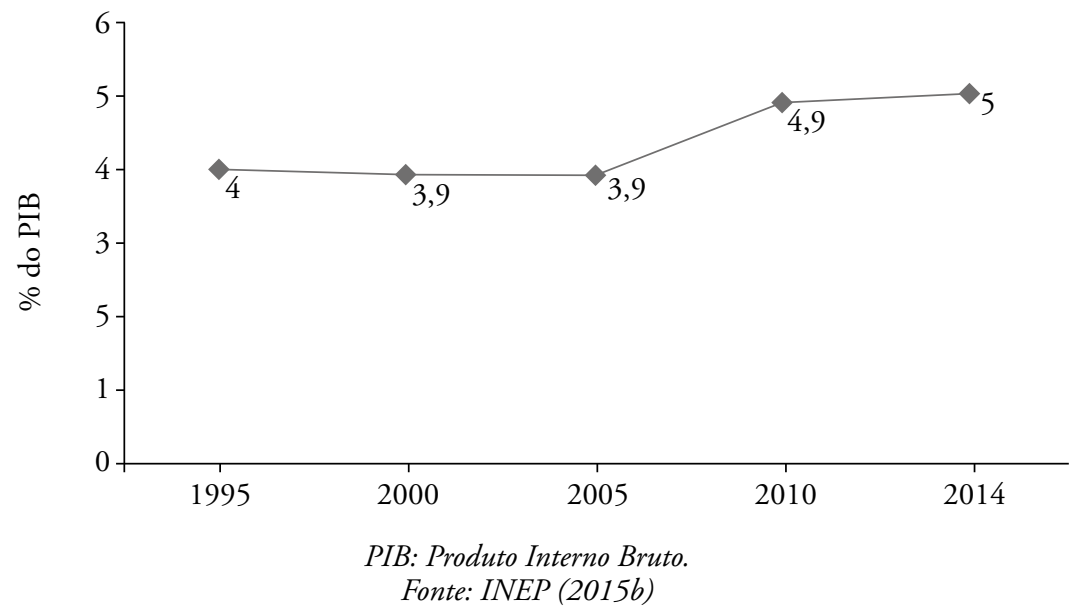


de 1,2\% do PIB. Já com relação ao Fundef, que vigorou compulsoriamente de 1998 a 2006, e o Fundeb, atualmente em vigor, o que se constata é que os recursos dos dois fundos estão totalmente atrelados ao PIB, uma vez que o crescimento apresentado entre 2006 e 2009 foi decorrência simplesmente da transição entre os fundos, que implicou em aumento de recursos, mas também no número de alunos abrangidos. Assim, os recursos do Fundef situaram-se na casa do 1,5\% do PIB, enquanto o Fundeb tem mobilizado cerca de 2,2\% do PIB, dos quais $0,2 \%$ advém da complementação da União.

Um efeito preocupante que, aparentemente, a política de fundos tem provocado é um desestímulo à incorporação de novos alunos, como mostra o Gráfico 4.

O que se constata é a ocorrência de uma reduçáo das matrículas no decorrer da existência dos fundos, com exceção dos anos iniciais do Fundef e na transição entre os fundos, quando novas etapas e modalidade foram incorporadas. Ao que tudo indica, ao contrário da fase inicial do Fundef, quando a maioria dos gestores desconhecia a lógica dos fundos, prefeitos e governadores têm optado por fazer o dinheiro render valendo-se da redução de matrículas. E isso ocorre em plena vigência do PNE 2014-2024, que apresenta várias metas que implicam em ampliação da oferta na educaçáo básica.

Se a política de fundos náo estimulou o aumento da oferta de vagas, resta analisar seu efeito equalizador e de garantia do padráo mínimo de qualidade previstos no $₫ 1^{\circ}$ do art. 211 da CF. O Gráfico 5, elaborado a partir dos dados consolidados do Fundeb para o ano de 2016 e usando como referência os valores do CAQi estabelecidos na Resoluçáo CEB/CNE no 8/2010, apresenta os avanços e os limites do atual desenho do Fundeb e mostra o impacto que seria a implantação do CAQi.

\section{Gráfico 3}

Evolução dos gastos da União com manutenção e desenvolvimento do ensino e dos recursos do Fundef/Fundeb - 2000 a 2016 (\% do Produto Interno Bruto).

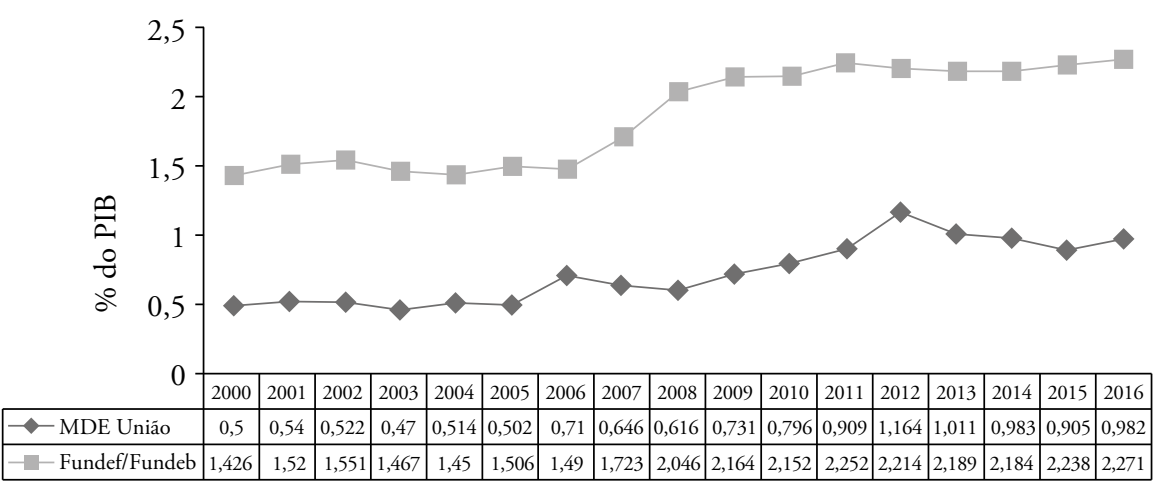

PIB: Produto Interno Bruto; MDE: manutenção e desenvolvimento do ensino; Fundef: Fundo de Manutenção e Desenvolvimento do Ensino Fundamental e de Valorização dos Profissionais do Magistério; Fundeb: Fundo de Manutenção e Desenvolvimento da Educaçâa Básica e de Valorização dos Profissionais da Educação.

Fonte: STN, 2018 (MDE-União) e FNDE, 2018 (FundeflFundeb). 
O Gráfico 5 oferece um retrato preciso dos limites da vinculação constitucional de recursos para a educação do ponto de vista federativo. Isso se evidencia no cenário em que não se considera a complementação atual da União ao Fundeb nem a simulação do CAQi (tom mais escuro no gráfico). Muito embora o Fundeb não represente a totalidade dos recursos vinculados, para as redes públicas estaduais e municipais, com exceção das redes municipais das capitais e de alguns municípios mais populosos, o valor por aluno disponibilizado pelo fundo corresponde a cerca de $80 \%$ dos recursos vinculados constitucionalmente e reproduz fielmente as diferenças entre as Unidades da Federaçáo. Nesse cenário, observa-se grande diferenciaçáo no valor disponível por aluno, que é funçáo direta da receita

\section{Gráfico 4}

Evolução das matrículas abrangidas pelo Fundef/Fundeb - 2008 a 2016 (× milhóes).

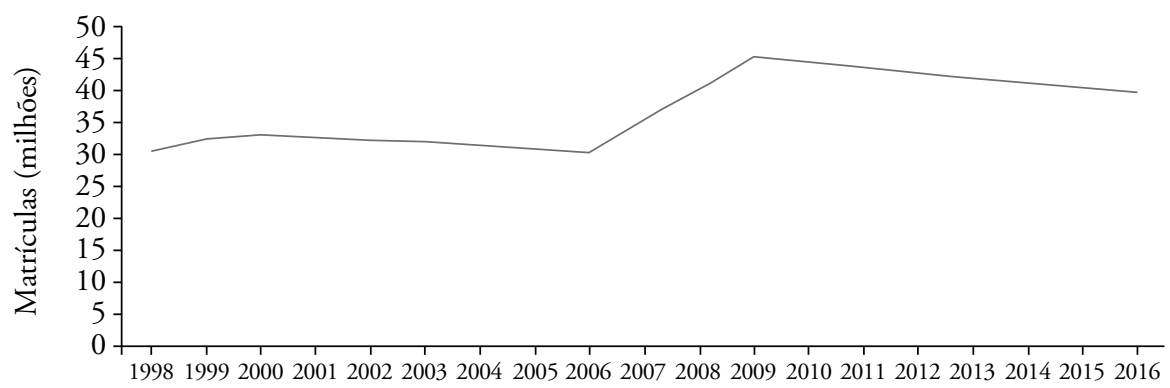

Fonte: FNDE, 2018a (relatório consolidado do Fundeb), vários anos.

\section{Gráfico 5}

Efeito no valor disponível por aluno do Fundeb, sem complementação, com a complementação atual da União e com o Custo Aluno-Qualidade inicial - 2016.

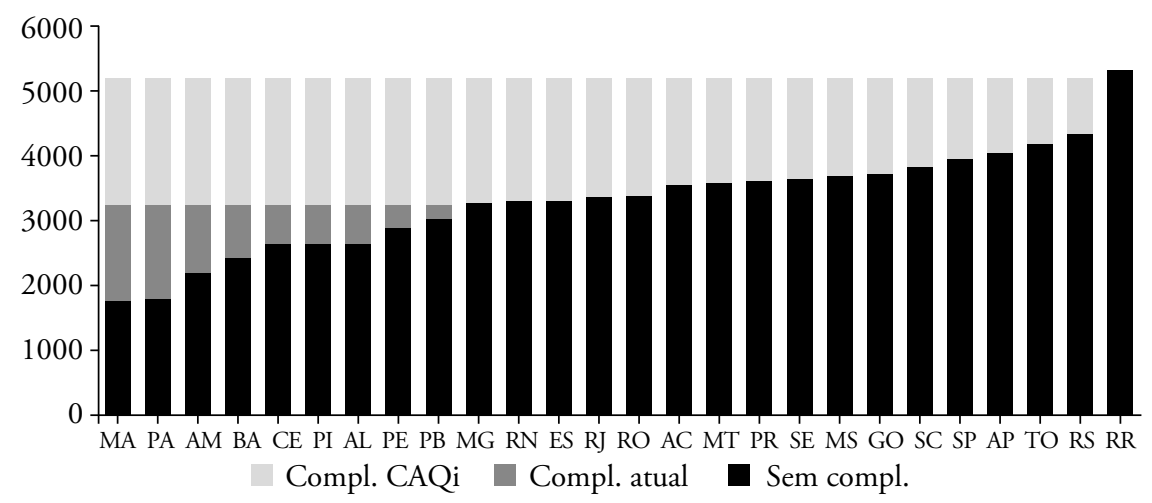

CAQi: Custo Aluno-Qualidade inicial.

Obs.: não se considerou o DF, porque boa parte do

financiamento do seu sistema de ensino advém de recursos federais.

Fonte: FNDE (2016) e CNDE, 2018 (valores do CAQi). (Simulaçôes feitas pelo autor). 
de impostos de cada unidade da federação e da amplitude do atendimento na educação básica. Assim, há os estados do Maranhão e do Piauí com um valor disponível por aluno-ano abaixo de R \$ 2.000, seguidos por Amazonas, Bahia, Ceará, Piauí, Alagoas, Pernambuco e Paraíba, com valores entre R $\$ 2.000$ e R \$ 3.000; acompanhados por Minas Gerais, Rio Grande do Norte, Espírito Santo, Rio de Janeiro, Rondônia, Acre, Mato Grosso, Paraná, Sergipe, Mato Grosso do Sul, Goiás, Santa Catarina, São Paulo e Amapá, situados entre R \$ 3.000 e R \$ 4.000, com Tocantins e Rio Grande do Sul em valores muito próximos desse limite superior; e, finalmente, Roraima, na faixa superior a $\mathrm{R} \$ 5.000$ por aluno-ano. A razão entre o maior valor disponível por aluno (Roraima) e o menor (Maranhão) é superior a três vezes. Se for considerada a razão entre a média do valor-aluno disponível das cinco Unidades da Federação com $\mathrm{R} \$$ /aluno mais elevado e a média das cinco com menores valores, chega-se a duas vezes. São desigualdades inaceitáveis dentro de um mesmo país. Além disso, como apontado na Tabela 1, antes dos fundos, havia ainda grandes discrepâncias no valor/aluno entre as redes estaduais e municipais dentro de um mesmo estado. Hoje, essa diferenciaçáo persiste apenas para as capitais e os municípios mais populosos, que possuem uma receita própria de impostos significativa, quando comparados com a rede estadual e com os demais municípios. Entretanto, tirando esses poucos casos, com os fundos houve uma aproximação nos gastos por aluno entre a rede estadual e a rede municipal de uma mesma unidade federada.

Em seguida, cabe analisar a situação atual de vigência do Fundeb, mas sem o CAQi (tom acinzentado no Gráfico 5). Em 2016, a União complementou o fundo com $0,2 \%$ do PIB, o que permitiu que nove estados fossem contemplados com recursos adicionais. Do ponto de vista do incremento no valor aluno, tem-se a seguinte situação: Maranhão, 86\%; Pará, 82\%; Amazonas, 48\%; Bahia, 35\%; Ceará, 27\%; Piauí, 26\%; Alagoas, 24\%; Pernambuco, 13\%; e Paraíba com um acréscimo de 7\%. Ou seja, pode-se dizer que apenas para os três primeiros houve uma ampliação significativa no valor disponível por aluno graças ao incremento da União. Essa constatação corrobora o que foi apontado por Pinto (2014). Contudo, dos 26 estados considerados, somente um terço recebeu complementação. Além disso, a razão entre o maior valor (R\$ 5.345) - de Roraima - e o menor valor (R\$3.250) - de Maranhão, Pará, Amazonas, Bahia, Ceará, Piauí, Alagoas, Pernambuco e Paraíba é superior a $60 \%$, o que mostra como ainda se está longe da equalização das oportunidades educacionais. Os dados mostram também como é difícil reduzir as desigualdades no país; 0,2\% do PIB correspondia a R \$ 13 bilhóes, em valores de 2016, valor considerável, mas que está longe de equalizar o valor disponível no âmbito do Fundeb e mais longe ainda para garantir o CAQi.

Finalmente, o Gráfico 5 mostra uma simulação dos efeitos no valor médio por aluno com a implantação do CAQi (tom mais claro). Nesse caso, o valor mínimo de referência sairia de $R$ \$ 3.250 para $R$ \$ 5.225 e, com exceção de Roraima, todos os demais estados receberiam complementaçáo da Uniáo. E mesmo em relação a Roraima, a diferença seria de $2,2 \%$. Ou seja, as simulaçóes apontam que, com a implantação 
do CAQi e considerando a matrícula atual, seria assegurado não só o padrão mínimo de qualidade, bem como a equalização, ao menos no âmbito do Fundeb, dos valores disponíveis por aluno. Para isso, contudo, a complementação da União ao Fundeb deveria sair de 0,2 para $1,1 \%$ do PIB, o que significa uma mudança radical, porém necessária, no papel do Governo Federal no financiamento da educação básica.

Cabe ainda uma observação derradeira sobre os dados de $\mathrm{R} \$$ /aluno apresentados no Gráfico 5: mesmo considerando a complementação para se atingir o CAQi, as quantias disponibilizadas por aluno-ano náo equivalem ao valor de duas ou três mensalidades de uma escola privada destinada à elite.

\section{Considerações finais}

Não há como ser otimista ao final deste trabalho, destinado a um balanço sobre os 30 anos dos preceitos envolvendo o financiamento à educação na CF de 1988. Nascida prenhe de utopias, sob a égide da luta contra a ditadura e da consolidação da vinculação constitucional de recursos para o ensino, a CF de 1988 vê, hoje, revogada essa mesma vinculação, no que se refere à União, com a aprovação da EC n. 95/2016. Trata-se de um duro golpe, que não deve, contudo, ofuscar as conquistas do período, nascidas de grande esforço de mobilizaçáo da sociedade civil e que garantiram avanços no acesso, redução das desigualdades e pequenos passos na garantia de um padrão básico de qualidade de ensino, como pode ser constatado no monitoramento das metas do PNE 2014-2024 (INEP, 2018). O mesmo relatório de monitoramento, contudo, mostra, para 2015, o gasto público para educação pública no patamar de $5 \%$ do PIB, o que indica como é dura a disputa pelo fundo público.

Os dados apresentados na segunda parte deste trabalho indicam, de um lado, um avanço na equalização do gasto por aluno com a política de fundos, em especial com o Fundeb, mas, de outro, ficam também evidentes os limites desse processo, caso se mantenha o desenho atual desse fundo. Eles ressaltam ainda o baixo valor disponível por aluno, mesmo em um cenário de queda de matrículas, quando seria necessária a sua expansão, em especial nas creches, no Ensino Médio e na EJA.

Vilipendiada pelas "forças do mercado", essa CF, fruto da luta pela redemocratizaçấo do país, foi e continua sendo um instrumento útil, uma arma de luta política e jurídica para todos aqueles que, nessas últimas três décadas, lutaram e permanecem lutando por uma escola pública de qualidade para todos os brasileiros. Mecanismos como o Fundeb, o PNE e o CAQi, desenvolvidos sob as asas dessa Carta Magna e nos limites da correlaçáo de forças que marcaram as gestóes de Lula e Dilma, mostram que, não obstante os retrocessos, é possível conceber instrumentos de políticas públicas que podem contribuir para a redução das desigualdades educacionais que marcam a história brasileira e que oferecem um horizonte de melhoria da qualidade da escola pública. 


\section{Referências}

ADRIÃO, T.; PERONI, V.M.V. Implicaçóes do Programa Dinheiro Direto na Escola para a gestão da escola pública. Educação \& Sociedade, v. 28, n. 98, p. 253-267, abr. 2007. http://dx.doi.org/10.1590/S0101-73302007000100013

ADRIÃO, T.; PINTO, J.M.R. Privatização da educação na América Latina: estratégias recentes em destaque. Educaçâo \& Sociedade, v. 37, n. 134, p. 11-15, mar. 2016. http://dx.doi.org/10.1590/ES0101-73302016162765

ALMEIDA, J.R.P. História da Instrução pública no Brasil (1500-1889). Brasília: INEPEPUC, 1989.

AMARAL, N. Para compreender o financiamento da educação básica no Brasil. Brasília: Líber Livro, 2012.

ARAÚJO, R.L.S. Desvendando o perfil dos gastos educacionais dos municípios brasileiros. Educação \& Sociedade, v. 33, n. 121, p. 1215-1233, dez. 2012. http://dx.doi. org/10.1590/S0101-73302012000400016

ARELARO, L.R.G. Financiamento e qualidade na educação brasileira. Algumas reflexôes sobre o documento "Balanço do primeiro ano do Fundef - Relatório MEC". In: DOURADO, L.F. (Org.). Financiamento da educação básica. Campinas: Autores Associados; Goiânia: Editora UFG, 1999. p. 27-46.

BRASIL. Constituição da República Federativa do Brasil. Brasília: Senado Federal, 1988.

. Emenda Constitucional no 1, de 17 de outubro de 1969. Edita o novo texto da Constituição Federal de 24 de janeiro de 1967. Brasília: Senado Federal, 1969.

Emenda Constitucional no 14, de 12 de setembro de 1996. Aprova o Fundo de Manutenção e Desenvolvimento do Ensino Fundamental e de Valorização do Magistério e dá outras providências. Brasília: Senado Federal, 1996.

. Emenda Constitucional no 53, de 20 de dezembro de 2006. Aprova o Fundo de Manutenção e Desenvolvimento da Educação Básica e de Valorização do Magistério e dá outras providências. Brasília: Senado Federal, 2006.

. Emenda Constitucional no 59, de 11 de novembro de 2009. Reduz progressivamente o efeito da Desvinculação das Receitas da União para a educação, autoriza o estabelecimento de meta, no Plano Nacional de Educação, de aplicação de recursos públicos em educação como proporção do produto interno bruto e dá outras providências. Brasília: Senado Federal, 2009.

Emenda Constitucional no 93, de 8 de setembro de 2016. Altera o Ato das Disposiçôes Constitucionais Transitórias para prorrogar a desvinculação de receitas da União e estabelecer a desvinculação de receitas dos Estados, Distrito Federal e Municípios. Brasília: Senado Federal, 2016a.

. Emenda Constitucional no 95, de 15 de dezembro de 2016. Institui o Novo Regime Fiscal e dá outras providências. Brasília: Senado Federal, 2016 b. 
Lei no 4.024, de 20 de dezembro de 1961 (LDB). Fixa as Diretrizes e Bases da Educação Nacional. Brasília: Senado Federal, 1961.

. Lei no 9.394, de 20 de dezembro de 1996. Estabelece as diretrizes e bases da educação nacional. Brasília: Senado Federal, 1996a.

Lei no 9.424, de 24 de dezembro de 1996. Dispóe sobre o Fundo de Manutenção e Desenvolvimento do Ensino Fundamental e de Valorização do Magistério, na forma prevista no art. $60, \$ 7^{\circ}$, do Ato das Disposiçôes Constitucionais Transitórias, e dá outras providências. Brasília: Senado Federal, 1996b.

. Lei no 13.005, de junho de 2014. Aprova o Plano Nacional de Educação - PNE e dá outras providências. Brasília: Senado Federal, 2014.

- Ministério da Educação. Retrato do Brasil: educação, cultural e desporto. Brasília: Ministério da Educação, 1985.

- Ministério da Fazenda. Fundo de Financiamento Estudantil: ausência de sustentabilidade e suas causas. Brasília: Ministério da Fazenda, jun. 2017.

- Secretaria do Tesouro Nacional. Demonstrativo das Despesas com Manutenção e Desenvolvimento do Ensino. Brasília: Secretaria do Tesouro Nacional, 2016c.

CAMPANHA NACIONAL PELO DIREITO À EDUCAÇÃO (CNDE). Cálculos do CAQi e do CAQ. São Paulo: Campanha Nacional pelo Direito à Educação, 2018. Disponível em: <http://www.custoalunoqualidade.org.br/calculos-do-caqi-e-do-caq>. Acesso em: 15. mar. 2018.

CARREIRA, D.; PINTO, J.M.R. Custo aluno-qualidade inicial: rumo à educação pública de qualidade no Brasil. São Paulo: Global, 2007.

CASTRO, J.A.; FERNANDES, M.A.C. Sistema de informaçôes sobre gastos públicos na área de educação. Brasília: IPEA, 1999.

CURY, C.R.J. Estado e políticas de financiamento em educação. Educação \& Sociedade, v. 28, n. 100, p. 831-855, out. 2007. http://dx.doi.org/10.1590/S0101-73302007000300010

DAVIES, N. FUNDEB: a redenção da educação básica? Educação \& Sociedade, v. 27, n. 96, p. 753-774, out. 2006. http://dx.doi.org/10.1590/S0101-73302006000300007

FUNDO NACIONAL DE DESENVOLVIMENTO DA EDUCAÇÃO (FNDE). Matrículas, coeficientes de distribuição de recursos e receita anual prevista por Estado e Município. Brasília: Fundo Nacional de Desenvolvimento da Educação, 2018a. Disponível em: <http:/www.fnde.gov.br/financiamento/fundeb/area-para-gestores/ dados-estatisticos>. Acesso em: 20 mar. 2018.

Repasse consolidado por UF, esfera de governo, origem em mês. Brasília: Fundo Nacional de Desenvolvimento da Educação, 2016. Disponível em: < http://www.fnde.gov. br/financiamento/fundeb/area-para-gestores/dados-estatisticos >. Acesso em: 20 mar. 2018.

- Valor anual por aluno estimado, no âmbito do Distrito Federal e dos Estados, e estimativa de receita do Fundeb. Brasília: Fundo Nacional de Desenvolvimento da 
Educação, 2018b. Disponível em: <http://www.fnde.gov.br/financiamento/fundeb/areapara-gestores/dados-estatisticos >. Acesso em: 20 mar. 2018.

INSTITUTO NACIONAL DE ESTUDOS E PESQUISAS EDUCACIONAIS ANÍSIO TEIXEIRA (INEP). Investimento público direto em educação. Brasília: INEP, 2015a. Disponível em: <http://portal.inep.gov.br/indicadores-financeiros-educacionais>. Acesso em: 16 mar. 2018.

. Percentual do Investimento público direto em educação em relação ao PIB. Brasília: INEP, 2015b. Disponível em: <http://portal.inep.gov.br/indicadores-financeiroseducacionais $>$. Acesso em: 16 mar. 2018.

Relatório do $2^{\circ}$ ciclo de monitoramento das metas do Plano Nacional de Educação2018. Brasília: INEP, 2018.

MINISTÉRIO DA EDUCAÇÃO (MEC). Censo Escolar. Brasília: MEC/INEP, 1997 a 2016. Disponível em: <http://inep.gov.br/censo-escolar>. Acesso em: 16 mar. 2018.

MARTINS, P.S. Fundeb, federalismo e regime de colaboração. Campinas: Autores Associados; Brasília: UnB, 2011.

MARTINS, P.S.; PINTO, J.M.R. Como seria o financiamento de um sistema nacional de educação na perspectiva do Manifesto dos Pioneiros da educação nova. In: CUNHA, C.; GADOTTI, M.; BORDIGNON, G.; NOGUEIRA, F. (Orgs.). O Sistema Nacional de Educação: diversos olhares 80 anos após o Manifesto. Brasília: Ministério da Educação/ Secretaria de Articulação com os Sistemas de Ensino, 2014.

MELCHIOR, J.C.A. Mudanças no financiamento da educação no Brasil. São Paulo: Autores Associados, 1997.

MONLEVADE, J. Educação Pública no Brasil: Contos \& De\$conto\$. Ceilândia: Idea, 1997.

MONLEVADE, J.; FERREIRA, E.B. O Fundefe seus pecados capitais. Ceilândia: Idea, 1997.

MORAIS, C.C.; OLIVEIRA, C.C. Aulas régias, cobrança do subsídio literário e pagamento dos ordenados dos professores em Minas Gerais no período colonial. Educação em Perspectiva, Viçosa, v. 3, n. 1, p. 81-104, jan./jun. 2012. https://doi.org/10.22294/eduper/ppge/ufv.v3i1.264

NUNES, D. Por que se sonega tantos impostos no Brasil? Carta Capital, 2017. Disponível em: <https://www.cartacapital.com.br/economia/por-que-se-sonega-tantos-impostos-nobrasil>. Acesso em: 16 mar. 2018.

OLIVEIRA, R.P.; ADRIÃO, T. O ensino fundamental. In: OLIVEIRA, R.P.; ADRIÃO T. (Orgs.). Organização do ensino no Brasil. São Paulo: Xamã, 2002.

PERONI, V.M.V. Política educacional e papel do Estado no Brasil dos anos 90. São Paulo: Xamã, 2003.

PERONI, V.M.V.; OLIVEIRA, R.T.C.; FERNANDES, M.D.E. Estado e terceiro setor: as novas regulações entre o público e o privado na gestão da educação básica brasileira. Educação \& Sociedade, v. 30, n. 108, p. 761-778, out. 2009. http://dx.doi.org/10.1590/S0101-73302009000300007 
PINTO, J.M.R. A política recente de fundos para o financiamento da educação e seus efeitos no pacto federativo. Educação \& Sociedade, v. 28, n. 100, p. 877-897, out. 2007. http://dx.doi.org/10.1590/S0101-73302007000300012

As implicaçóes financeiras da municipalização do ensino de $1^{\circ}$ grau. Dissertação (Mestrado). Faculdade de Educação da UNICAMP, Campinas, 1989.

. Federalismo, descentralização e planejamento da educação: desafios aos municípios. Cadernos de Pesquisa, v. 44, p. 624-644, 2014. http://dx.doi.org/10.1590/198053142946

. Financiamento da educação no Brasil: um balanço do governo FHC (19952002). Educação e Sociedade, v. 23, p. 108-135, 2002. http://dx.doi.org/10.1590/S0101$\underline{73302002008000008}$

. Os recursos para Educação no Brasil no contexto das finanças públicas. Brasília: Plano, 2000.

. Um fundinho chamado "fundão". In: DOURADO, L.F. (Org.) Financiamento da educação básica. Campinas: Autores Associados; Goiânia: Editora UFG, 1999. p. 85-98.

- Uma análise da destinação dos recursos públicos, direta ou indiretamente, ao setor privado de ensino no Brasil. Educação \& Sociedade, v. 37, n. 134, p. 133-152, mar. 2016. http://dx.doi.org/10.1590/ES0101-73302016157682

RECEITA FEDERAL. Carga Tributária no Brasil 2015. Brasília: Receita Federal do Brasil, 2016. ROMANELLI, O. de O. História da Educação no Brasil. 28. ed. Petrópolis: Vozes, 2003.

SALDAÑA, P. Alckmim terá de excluir aposentado de gasto mínimo com educação, diz TCE. Folha de S.Paulo, 2017. Disponível em: <http://www1.folha.uol.com.br/ educacao/2017/06/1894686-alckmin-tera-de-excluir-aposentado-de-gasto-minimo-comeducacao-diz-tce.shtml>. Acesso em: 16 mar. 2018.

SENA, P. A legislação do Fundeb. Cadernos de Pesquisa, v. 38, n. 134, p. 319-340, ago. 2008. http://dx.doi.org/10.1590/S0100-15742008000200004

SUPREMO TRIBUNAL FEDERAL (STF). Ação Direta de Constitucionalidade nº 5.719. Brasília: STF, 2017.

SECRETARIA DO TESOURO NACIONAL (STN). Demonstrativo das despesas com educação da União. Brasília: Secretaria do Tesouro Nacional, 2018. Disponível em: <http:// www.tesouro.fazenda.gov.br/demonstrativos-fiscais>. Acesso em: 20 mar. 2018.

Recebido em 12 de junho de 2018.

Aceito em 26 de julho de 2018. 